\title{
Learning Interest on Student Centered Learning Approach in Disruptive Era
}

\author{
Jeane Marie Tulung*, Mercy W. K. Waney, Yunita Sumakul \\ Institut Agama Kristen Negeri \\ Manado, Indonesia \\ *jeanetulung@yahoo.com, mercywaney79@gmail.com,01yunitasumakul@gmail.com
}

\begin{abstract}
Student Centered Learning is one of learning approaches focused on students. The aim of this study was to describe and explain student learning interest using studentcentered learning approach. This study was a qualitative research with descriptive case study method. Data was collected from observations, interviews, and documentation. The result showed that students were happy involved in the lesson from the beginning to the end. The students gave attention/focused on the lesson or on instructor's explanation and they were active in learning activities in the class.
\end{abstract}

Keywords: learning interest, student centered learning, disruptive era

\section{INTRODUCTION}

Education is very essential in human's life because through education, one can find his potential and develop himself. One of the activities in education is carrying out learning and teaching process. Teachers need to invent appropriate learning approaches to be used in the teaching and learning process so that the purpose of teaching can be achieved. One of the approaches used is student centered learning.

Student-Centered Learning is not a method, it is more of a mindset, a paradigm for looking at education. Student centered simply means that students become more active, not only in doing learning activities, such as speaking, calculating, experimenting, writing and creating videos and web-based materials, but also in thinking and shaping their own learning [1]. Student-Centered Learning (SCL) approach focuses on the needs of students by making them responsible in learning and by reducing their reliance on other students, teachers, and administrators. Student-Centered Learning describes ways of thinking in learning and teaching that emphasize students' responsibility on activities such as planning learning, interacting with teachers and other students, researching, and assessing learning [2].

There are ten elements in Student-Centered Learning: 1) Students and teachers as co-learners; 2) Student-student interaction; 3) Learner autonomy; 4) focus on meaning; 5) Curricular integration; 6) Diversity; 7) Thinking skills; 8) Alternative assessment; 9) Learning climate; 10) Motivation [3].
Student-Centered Learning method includes active learning (the responsibility of learning is on the learners), competitive learning (learning motivated by competition), inductive teaching and learning (developing general principles through observations) placing the emphasis on learning instead of teaching. Inductive teaching and learning include a range of instructional methods such as: inquiry-based learning (involvement in learning that leads to understanding); casebased instruction (students' engagement approach in discussion to specific situations, typically real-world examples); problembased learning (students engagement in conceptual open-ended complex situations); project-based learning (an instructional approach built upon real life activities that engages students interest and motivation); discovery learning (students are assigned problem or question without any guidance or directions from educators on their efforts to solve it); and justin-time teaching (students acquire knowledge or skills as needed) [2].

The progress places the students at the center of the learning process as the major factor in acquiring knowledge, while the instructor becomes a facilitator of learning. It also puts the students' interests and abilities at the forefront of the learning activity that establishes students as the major factor in acquiring knowledge and in making the lessons meaningful. There are tremendous advantages to teachers and students involved in SCL. Students will cultivate learning and develop new skills while gaining the importance of knowing that acquiring knowledge is a lifelong process. Student-Centered Learning promotes an integrated curriculum that reinforces student motivation, promotes peer communication, and reduce disruptive behavior. Student-Centered Learning allows the students to be autonomous in their learning by reducing the reliance on the teacher. Research indicates that students learn much more by doing things and getting feedback as soon as possible. When classes are lively and enjoyable, interest in the learning process increases and the quality of information can be dealt with dramatically improvement. In addition, adjusting the difficulty of task to the skill and ability of the students results in more positive learning [4]

Interest is the central force that drives the whole machine of the teaching learning process. It means by giving interest students will be more focused and easy to understand the material given by the teacher. Strong interest will influence 
students' activity, because it will make them doing something interesting. In this case, this is called an interest in learning [4]. According to Nasution, interest is a psychological statement showing the occurrence of concentrations of attention, feeling and will to an object, since it is stunning. The indicators to find out one's interest in learning are: a) the concentrations of attention, feeling, and mind of the subject to the learning due to the interest; b) the lesson enjoyment; c) the will or tendency of the subject to involve actively in learning to get a good result.

Interest in Student-Centered Learning has been a longstanding approach among educators in primary, secondary and higher education. Numbers of researches, policies and practices claiming using student centered approach have continued to grow [5].

In the literature of cognitive psychology, interest is defined as one's willful engagement with a specific object, activity, or event and this engagement is featured by positive affect, focused attention, and concentration. People are not interested in general senses but they need specific classes of objects to be interested in [6].

Students listen to lectures, participate in group discussions, read learning materials, solve problems, work on personal projects, and so forth, so that, their sense of 'how things are going' mostly reflects their underlying motivational status while doing these things. In this sense, motivational status refers to the state of students' needs and goals during the flow of instructions. Things are going well when classroom events are involved and be relevant to students' needs and personal strivings. Interest can be understood as an emotional signal or an effective confirmation that classroom activity is (or is not) addressing, involving, and proving to be relevant to students' needs and strivings. Interest is important to classroom learning for two reasons. First, interest vitalizes engagement. It motivates the kind of classroom engagement that helps students translate an interest in a topic into learning about that topic. Second, interest replenishes students' motivational and cognitive resources [7].

\section{Study Methods}

\section{A. Research Approach}

This study was qualitative using descriptive case study technique. Qualitative research focuses on phenomena occurring in natural settings, and the data are analyzed without using statistics. Qualitative research always takes place on the field or wherever the participants normally conduct their activities. It is often referred to as field research. Qualitative research entails observation and/or unstructured interviewing in natural settings. The data are collected in a spontaneous and open-ended style [8].

A case study is part of qualitative research which explores a particular case more deeply by involving information collecting from various sources. By understanding the case in depth, the writer would capture the importance of interests of community, organization or certain community. The form of case studies can be descriptive, exploratory, and explanatory [9]. As a case study, it is a deeply comprehensively detailed study of particular object titled 'Student interest towards the use of Student-Centered Learning approach'. Thus, this study described and explained how students' interest in learning at the Eye Level Learning Center was.

\section{B. Subjects of the Study}

The subject of this study was the students studying at Eye Level for at least 3 months. The number of participants were 6 students.

\section{Data Collection Technique}

The data collection procedure in qualitative research involves four basic types with their strengths and limitations, namely observation, interview, documents, audio and visual materials [10]. In this study, the technique of collecting data used by the writer is observations, interviews, and documentation. (1) Observation is involved whenever a recorder, human or mechanical, observes events for the purpose of collecting information and making a permanent record of them. This is a broad definition since observation is a versatile data collection method. Observation has been used as the data collection method both in highly structured forms of research and in flexible method studies in participant observation form [11]. The writers used repeated observation method where he was repeatedly observing student's behavior specifically on the field. The writers tried to answer the problems through observing the students studying at the Eye Level Learning Center. The writers used participant observation where they were actively involved in observing activities. They used observation guidelines in checklist and field notes forms. Observations made by the writers are to directly and naturally observe all activities in teaching and learning process. (2) Interviews; in this study writers used interviews as one of the data collection techniques where the writers and participants asking and answering questions to achieve certain goals. Interviews were conducted with students, instructors and parents by asking "how" and "why" questions on the subjects to find the cause and effect of the problem. According to Yin, case study research has its advantages when the question "how" and "why" are directed to a series of contemporary events, where the writer has only a very small chance or has no chance at all to control the events [12]; (3) Documentation, a written material or film as a source of data, was used by the writers to test, interpret, and even predict [13]. Documents used were in the form of Eye Level Learning Center profiles, Standard Operating Procedures Eye Level Learning Center, students' data, photos of student activities, videos, and sound recordings during interviews.

\section{Data Analysis}

According to Miles and Huberman, qualitative data analysis consists of three components that constitute concurrent flows of activity: data reduction, data display, and conclusion drawing and verification. (1) Data reduction refers to the process of selecting, focusing, simplifying, abstracting, and transforming the data that appears in field notes or 
transcriptions. Activities such as writing summaries, coding and clustering chunks of data or identifying themes may be carried out in order to reducing data; (2) Data display, the second major analysis activity, involves the organized and condensed assembly of information that permits conclusion drawing. Particularly, when qualitative data are displayed as extended text that is poorly structured and bulky, the goal is to find better forms of data displays such as matrices, graphs, charts and networks that make information more immediately accessible; (3) The third concurrent stream of activity is conclusion drawing and verification. Here, the writers note regularities, patterns, explanations, possible configurations and propositions. At the same time, this conclusion has to be tested continuously for their plausibility and confirmability as the analysis proceeds [10].

In this study, the writers used data analysis with the following stages: (1) Data reduction. After the writers collecting data from observations, interviews, and documentation, they simplified the data. It was done to get more data focused on the research problem to find a clear and precise picture; (2) Data display. From the data reduction result, the writers presented the data in a better form; (3) Drawing conclusion and verification was to get final results of the research conducted and to present it.

\section{RESULTS AND DISCUSSION}

This study was conducted at the Eye Level Learning Center located at Kompleks Bahu Mall Manado, North Sulawesi. Eye Level is a center of learning English, Mathematics, and Chinese for children aged 5-15 years old.

Based on the observations, students in each class are not more than 8. Each student gets a table and chairs equipped with supporting facilities such as air conditioner, whiteboard, LCD, video player, and headset. In addition, students get a booklet at each meeting and props too. The duration of study for each meeting is 60 minutes. The learning activities are working on questions in the booklet, listening and viewing learning CDs using video players and headsets, working on group assignments, role playing, problem solving, one to one coaching. Students show good focus / attention when the instructor explains the material, they are actively working on group assignments, and they arrive on time according to the schedule.

Interviews with $\mathrm{CK}$, a student, revealed that he was eager to learn because he was happy to meet classmates and instructors. Textbook and Workbook provided by instructors were always done on time. Next, an interview with IT, a student, said that he enjoyed studying with his classmates at Eye Level. He was excited given a group assignment by the instructor because he could interact with other friends. Student KT said that he enjoyed studying at Eye Level because of the pleasant classroom situation. In addition, the instructor could also explain the lesson well. Student CK said that he liked to study at Eye Level because it facilitates students with various activities. The most preferred activities are working on booklets and role playing. Student MN said that he liked to be involved in group activities to work on a project. He was never late for class or for doing tasks on the workbook. Student LT said that he could do the textbook and workbook tasks on time. He liked listening to English conversation on the learning CD and working on story problems.

Interview with $\mathrm{AS}$, an instructor, said that learning at Eye Level focuses on student activities, aiming to prepare and accustom students to become active learners for ages. Students are given varied learning methods and the teaching and learning process in class goes well and students show positive responses. Learning progress increases, as seen from the changes that students become active in class and can work on one booklet per meeting. There are even some students who can work on two booklets in one meeting. Whereas instructor MR said that students studying at Eye Level showed significant changes in learning outcomes. Many activities are carried out in the classroom. But students look more excited when given instructions to work on assignments that involve groups. In addition, students show increased focus in learning. Students become more attentive to instructor explanations and active in the learning process.

Interview with a student's mother, $\mathrm{MN}$, said that her child was so eager to work on the workbook given by the instructor. Previously, he did it with the help of parents but after several meetings he could do the problems himself in the workbook. Furthermore, KL's mother said that her child always seemed eager to share her learning activities at Eye Level. He also always worked on workbooks given by instructors.

Interest is not a heredity. It is shaped from innate personality and experience factors which have interacted densely with one self. The process of interest shaping is closely related to determining one's likes and dislikes on an object/activity which occurs as the result of experiences or information obtained. According to Crow and Crow, there are three factors in arousing interest, namely: (a) Self-motivation factor. It is a curiosity or a motivation to produce something new and different. This motivation can make one interested in studying mechanics, conducting scientific research or doing other challenging activities. The inner motivation factor is one's perception about himself, pride, personal wishes, needs, will, satisfaction, and achievement expected. b) Social Motive Factor is an interest in the effort of self-development from and into the science which probably inspired by the passion to get skills for work or the passion to get reward from family or friends; c) Emotional factor is interest related to feeling and emotion, for example, success will result in satisfaction and enhance interest. However, failure can destroy one's interest. [10]. Student Centered Learning is a learning approach which involves students actively in the learning process with some varied learning methods. Students learn new things with various methods to stimulate the happy feeling and the active involvement in learning activities.

\section{CONCLUSION AND IMPLICATION}

Based on the results of the research done, students who learn using the Student-Centered Learning approach feel happy to follow lessons from beginning to end, pay attention/focus on 
[2] A. Szopa, W. Karwowski and PO. de Pablos, Academic entrepreneurship and technological innovation: a business management perspective. USA: Information Science Reference, 2013, pp.116-117.

lessons or instructor explanations, be active in learning activities in class, and have time discipline.

Determining approaches and methods in student's learning is an important thing needed to be prepared by the teachers. Students who learn using the Student-Centered Learning approach show interest, attention, and active in the learning process. The results of this study can be a reference for educational institutions and also for the instructors in determining the appropriate approach and learning methods for students to achieve the learning objectives.

\section{ACKNOWLEDGMENT}

We want to thank all the people who have supported the implementation of this research process and publication. We hope that this research can be a reference for educational institutions and also for teaching staff to achieve educational goals.

\section{REFERENCES}

[3] G.M. Jacobs and WA. Renandya, Student centered cooperative learning. Switzerland: Springer, 2019, pp.1.

[4] E. Spooner, Interactive student centered learning (a cooperative approach to learning). London: Rowman \& Littlefield, 2015, pp. 73-74, 80-81.

[5] S. Lea, D. Stephenson and J. Troy, Higher education students, attitudes to student-centred learning: Beyond Educational Bulimia? Studies in Higher Education, vol. 28, pp. 3, 321-334.

[6] T.B. Tin, Stimulating student interest in language learning. London: Springer Nature, 2016, pp. 28

[7] K.A. Renninger, M. Nieswandt, and S. Hidi, Interest in mathematics and science learning. USA: American Educational Research Association, 2015, pp. 81,84.

[8] S.L. Jackson, Research methods. USA: Thomson Wadsworth, 2008, pp 88.

[9] J.R. Raco, Metode penelitian kualitatif. Jakarta: PT. Grasindo, 2010, pp. 49-50.

[10] A. Daniel, Perception gaps between headquarters and subsidiary managers. Germany: Gabler, 2009, pp.138.

[11] J.W. Anastas, Research design for social work and the human services. 2nd Ed. New York: Columbia University Press, 1999, pp.349.

[1] G.M. Jacobs, W.A. Renandya and M. Power, Simple, powerful, powerful strategies for student-centered learning. Switzerland: Springer, 2016, pp. 1.

[12] R.K. Yin, Studi kasus: desain dan metode. Jakarta: PT RajaGrafindo Persada, 2012, pp. 13

[13] J.L. Moleong, Metode penelitian kualitatif. Bandung: PT. Remaja Rosda Karya, 2007, pp. 219. 